\title{
Infiltration of central nervous system in adult acute myeloid leukaemia
}

\author{
M J PIPPARD, S T CALLENDER, P W E SHELDON
}

British Medical fournal, 1979, 1, 227-229

\section{Summary and conclusions}

Out of 64 consecutive unselected patients with acute myeloid leukaemia studied during 1973-6, five developed clinical evidence of spread to the central nervous system (CNS). Neuroradiological examination showed cerebral deposits in three, in whom rapid symptomatic relief was obtained with radiotherapy. In two of these patients who developed solid intracranial deposits haematological remission could be reinduced or maintained; they were still alive 86 and 134 weeks later. When patients presented with spread to the CNS complicating generalised uncontrolled leukaemia they had short survivals.

CNS infiltration may respond dramatically to appropriate treatment provided that it is not associated with generalised uncontrolled leukaemia, which has a poor prognosis. In view of this, routine "prophylaxis" of the CNS in adult acute myeloid leukaemia does not seem justified at present.

\section{Introduction}

In acute lymphoblastic leukaemia (ALL) in children the incidence of initial relapse in the meninges is over $50 \%$. This may be strikingly reduced by "prophylaxis" to the central nervous system (CNS), and the number of children achieving prolonged disease-free survival is thereby greatly increased. ${ }^{12}$ In acute myeloid leukaemia (AML) patients are now surviving longer due to improved drug and supportive treatment, and increasing numbers of cases of CNS infiltration have been observed in both children ${ }^{3}{ }^{4}$ and adults. ${ }^{5}$ The question of whether to give prophylactic cranial irradiation and intrathecal cytotoxic drugs as in ALL has therefore been raised. ${ }^{-9}$ The

\section{Radcliffe Infirmary, Oxford OX2 6HE}

M J PIPPARD, BSC, MRCP, research fellow, Nuffield department of clinical medicine

S T CALLENDER, DSC, FRCP, consultant physician, Nuffield department of clinical medicine

P W E SHELDON, MA, FRCR, consultant neuroradiologist, department of radiology decision to introduce such treatment would depend on the following. (1) The overall incidence of spread to the CNS in AML, which would determine the number of patients subjected unnecessarily to prophylaxis; (2) when in the course of the disease CNS infiltration occurs-that is, whether it tends to accompany terminal drug-resistant disease or whether by acting as a "sanctuary site" for leukaemia cells it precedes haematological relapse; and (3) how responsive established CNS leukaemia in AML is to appropriate treatment.

In this report we discuss these problems in the light of our experience in diagnosing and treating CNS leukaemia in a series of unselected adult patients with AML.

\section{Patients and treatment}

Between 1973 and 1976, 64 consecutive unselected patients aged 15-72 years (median 51 years) with AML were treated in Oxford by the protocol of the Medical Research Council's sixth AML (immunotherapy) trial. ${ }^{10}$ Induction chemotherapy consisted of five-day courses of daunorubicin and cytarabine repeated at 10-day intervals. When haematological remission was obtained patients received further courses of this treatment alternating with thioguanine and cytarabine at monthly intervals and were randomised as to whether they were also given immunotherapy (weekly BCG and injections of irradiated leukaemic myeloblasts). Chemotherapy was stopped after one year of maintenance; the immunotherapy was continued until relapse. Lumbar puncture was not done routinely at any stage in asymptomatic patients.

\section{Results}

Five of the 64 patients ( $8 \%$ ) developed clinically evident CNS infiltration. Tables I and II summarise details of these patients. Thirty-eight of the 64 patients obtained a first remission with a median duration of 41 weeks. Of these, four $(11 \%)$ subsequently developed leukaemic spread to the CNS. Of the 19 patients still in first remission at one year, three $(16 \%)$ subsequently developed overt CNS disease. CNS disease terminated first remission in only one patient (case 1), and this coincided with a haematological relapse. All of the remaining four patients had experienced one haematological relapse or had never achieved remission, and three had active systemic disease when spread to the CNS was diagnosed.

In three of the five patients neuroradiology showed leukaemic deposits in the brain (figs $1,2 a, 3$ ). These were highly radiosensitive, and treatment resulted in rapid symptomatic improvement. In the two in whom the systemic leukaemia was also brought under control the subsequent computerised axial tomographic (CAT) scans have

TABLE I-Presenting features of acute myeloid leukaemia in five patients who subsequently developed CNS infiltration

\begin{tabular}{|c|c|c|c|c|c|c|c|c|c|c|c|c|c|}
\hline \multirow{3}{*}{$\begin{array}{l}\text { Case } \\
\text { No }\end{array}$} & \multirow{3}{*}{ Sex } & \multirow{3}{*}{$\begin{array}{c}\text { Age } \\
\text { (yrs) }\end{array}$} & \multicolumn{4}{|c|}{ Peripheral blood counts } & \multicolumn{4}{|c|}{ Bone marrow (all hypercellular) } & \multicolumn{2}{|c|}{ Muramidase $(\mathrm{mg} / \mathrm{l})$} & \multirow{3}{*}{ Variant of AML } \\
\hline & & & \multirow{2}{*}{$\underset{(\mathrm{g} / \mathrm{dl})}{\mathrm{Hb}}$} & \multirow{2}{*}{$\begin{array}{c}\text { White } \\
\text { cells } \\
\left(\times 10^{\circ} / 1\right)\end{array}$} & \multirow{2}{*}{$\begin{array}{c}\text { Blast } \\
\text { cells } \\
\left(\times 10^{\circ} / 1\right)\end{array}$} & \multirow{2}{*}{$\begin{array}{l}\text { Platelets } \\
\left(\times 10^{\circ} / 1\right)\end{array}$} & \multirow{2}{*}{$\begin{array}{c}\% \\
\text { blasts }\end{array}$} & \multicolumn{3}{|c|}{ Cytochemistry } & \multirow{2}{*}{$\underset{\text { (normal 3-9) }}{\text { Plasma }}$} & \multirow{2}{*}{$\underset{\text { (normal }}{\text { Urine }}<1)$} & \\
\hline & & & & & & & & $\begin{array}{c}\text { Sudan } \\
\text { black }\end{array}$ & Peroxidase & $\begin{array}{c}\text { Per-iodic- } \\
\text { acid } \\
\text { Schiff }\end{array}$ & & & \\
\hline $\begin{array}{l}1 \\
2 \\
3 \\
4 \\
5\end{array}$ & $\begin{array}{l}M \\
M \\
M \\
F \\
M\end{array}$ & $\begin{array}{l}54 \\
63 \\
38 \\
64 \\
51\end{array}$ & $\begin{array}{l}13 \cdot 0 \\
10 \cdot 0 \\
11 \cdot 6 \\
10 \cdot 6 \\
14 \cdot 0\end{array}$ & $\begin{array}{r}150 \\
3 \cdot 1 \\
85 \\
110 \\
43\end{array}$ & $\begin{array}{l}75 * \\
1 \cdot 5 \\
56 \\
46 \\
16\end{array}$ & $\begin{array}{r}40 \\
100 \\
<10 \\
30 \\
70\end{array}$ & $\begin{array}{l}60 \dagger \\
85 \\
78 \\
92 \\
90\end{array}$ & $\begin{array}{l}\text { ND } \\
+ \\
\text { ND } \\
+ \\
+\end{array}$ & $\begin{array}{c}+ \\
+ \\
+ \\
+ \\
+ \\
\text { ND }\end{array}$ & $\begin{array}{l}\bar{z} \\
\bar{z} \\
\overline{-}\end{array}$ & $\begin{array}{l}\text { ND } \\
\text { ND } \\
43 \\
\text { ND } \\
80\end{array}$ & $\begin{array}{r}\text { ND } \\
\text { ND } \\
18 \\
1300 \\
130\end{array}$ & $\begin{array}{l}\text { Promyelocytic } \\
\text { Myeloid } \\
\text { Myelomonocytic } \\
\text { Myelomonocytic } \\
\text { Monocytic }\end{array}$ \\
\hline
\end{tabular}

*Plus $75 \times 10^{\%} / 1$ promyelocytes. 
TABLE II-Leukaemic activity at time of spread to central nervous system (CNS), and response to treatment

\begin{tabular}{|c|c|c|c|c|c|c|c|c|c|c|c|}
\hline \multirow{4}{*}{$\begin{array}{l}\text { Case } \\
\text { No }\end{array}$} & \multirow{4}{*}{$\begin{array}{c}\text { Weeks } \\
\text { from } \\
\text { diagnosis } \\
\text { of } \\
\text { leukaemia }\end{array}$} & \multicolumn{5}{|c|}{ Disease activity at CNS presentation } & \multicolumn{3}{|c|}{ Treatment and response } & \multirow{4}{*}{$\begin{array}{c}\text { Survival } \\
\text { after } \\
\text { CNS } \\
\text { diagnosis } \\
\text { (weeks) }\end{array}$} & \multirow{4}{*}{$\begin{array}{l}\text { Necropsy } \\
\text { results }\end{array}$} \\
\hline & & \multirow{3}{*}{ Clinical } & \multicolumn{3}{|c|}{ CNS disease } & \multirow{3}{*}{$\begin{array}{l}\text { Systemic } \\
\text { disease }\end{array}$} & \multirow{3}{*}{$\begin{array}{l}\text { Systemic } \\
\text { response }\end{array}$} & \multicolumn{2}{|c|}{ CNS } & & \\
\hline & & & \multirow{2}{*}{$\begin{array}{l}\text { CSF blast } \\
\text { count } \\
\left(\times 10^{8} / 1\right)\end{array}$} & \multicolumn{2}{|c|}{ Brain scans } & & & \multirow{2}{*}{ Treatment } & \multirow{2}{*}{ Response } & & \\
\hline & & & & ${ }^{9} \mathrm{~m}$ Technetium & CAT & & & & & & \\
\hline 1 & 99 & $\begin{array}{l}\text { Headache and } \\
\text { neck pain. } \\
\text { Left facial } \\
\text { weakness }\end{array}$ & 5 & Positive (fig 1) & Not done & $\begin{array}{l}\text { Simultaneous } \\
\text { haematological } \\
\text { relapse from } \\
\text { first remission }\end{array}$ & $\begin{array}{l}\text { Second } \\
\text { remission } \\
\text { obtained }\end{array}$ & $\begin{array}{l}3300 \text { rads } \\
\text { cranial } \\
\text { irradiation. } \\
\text { Cytarabine } \\
\text { given } \\
\text { intrathecally }\end{array}$ & $\begin{array}{l}\text { Symptomatic } \\
\text { relief. } \\
\text { Clearance of } \\
\text { CSF blasts. } \\
\text { CAT scan at } \\
\text { week } 189 \\
\text { normal }\end{array}$ & $>134$ & \\
\hline \multirow[t]{3}{*}{2} & 173 & Neck pain & 10 & Normal & Not done & $\begin{array}{l}\text { In second } \\
\text { remission but } \\
\text { mild marrow } \\
\text { hypoplasia }\end{array}$ & $\begin{array}{l}\text { Remained in } \\
\text { second } \\
\text { remission }\end{array}$ & $\begin{array}{l}\text { Intraventricular } \\
\text { methotrexate } \\
\text { and } \\
\text { cytarabine } \\
\text { (Ommaya } \\
\text { reservoir) }\end{array}$ & $\begin{array}{l}\text { Partial } \\
\text { symptomatic } \\
\text { relief }\end{array}$ & & \\
\hline & 207 & $\begin{array}{l}\text { Drowsy, } \\
\text { memory loss. } \\
\text { Right-sided } \\
\text { paraesthesiae } \\
\text { and ataxia }\end{array}$ & 0 & Not done & $\begin{array}{r}\text { Positive } \\
\text { (fig 2a) }\end{array}$ & $\begin{array}{l}\text { In second } \\
\text { remission but } \\
\text { mild marrow } \\
\text { hypoplasia }\end{array}$ & $\begin{array}{l}\text { Remained in } \\
\text { second } \\
\text { remission }\end{array}$ & $\begin{array}{l}2100 \text { rads } \\
\text { cranial } \\
\text { irradiation. } \\
\text { Cytarabine by } \\
\text { reservoir }\end{array}$ & $\begin{array}{l}\text { Symptomatic } \\
\text { relief. } \\
\text { CAT scan at } \\
\text { week 214 } \\
\text { normal (fig 2b) }\end{array}$ & & \\
\hline & 233 & $\begin{array}{l}\text { Severe pain in } \\
\text { right arm and } \\
\text { thigh } \\
\text { (presumed } \\
\text { spread to root) }\end{array}$ & 0 & Not done & Normal & $\begin{array}{l}\text { In second } \\
\text { remission but } \\
\text { mild marrow } \\
\text { hypoplasia }\end{array}$ & $\begin{array}{l}\text { Remained in } \\
\text { second } \\
\text { remission }\end{array}$ & $\begin{array}{l}1200 \text { rads to } \\
\text { cervical spine. } \\
1200 \text { rads to } \\
\text { lumbar spine }\end{array}$ & $\begin{array}{l}\text { Symptomatic } \\
\text { relief }\end{array}$ & $>86$ & \\
\hline 3 & 115 & $\begin{array}{l}\text { spread to root) } \\
\text { Backache, } \\
\text { headache. } \\
\text { Papilloedema. } \\
\text { Right third } \\
\text { nerve palsy }\end{array}$ & Not done & Not done & $\begin{array}{l}\text { Positive } \\
\text { (fig 3) }\end{array}$ & $\begin{array}{l}\text { Uncontrolled } \\
\text { leukaemia in } \\
\text { second relapse }\end{array}$ & No response & $\begin{array}{l}900 \text { rads } \\
\text { cranial } \\
\text { irradiation }\end{array}$ & $\begin{array}{l}\text { Partial } \\
\text { symptomatic } \\
\text { relief }\end{array}$ & 3 & Not done \\
\hline 4 & 40 & $\begin{array}{l}\text { nerve paisy } \\
\text { Headache }\end{array}$ & 1250 & Normal & Not done & $\begin{array}{l}\text { Marrow and } \\
\text { skin in relapse } \\
\text { from first } \\
\text { remission }\end{array}$ & Partial control & $\begin{array}{l}\text { Intrathecal } \\
\text { methotrexate } \\
\text { and } \\
\text { cytarabine }\end{array}$ & $\begin{array}{l}\text { Symptomatic } \\
\text { relief. } \\
\text { Clearance of } \\
\text { CSF blasts. } \\
\text { Terminal } \\
\text { recurrence of } \\
\text { headache and } \\
\text { CSF blasts }\end{array}$ & 39 & $\begin{array}{l}\text { Arachnoid and } \\
\text { perivascular } \\
\text { infiltration }\end{array}$ \\
\hline 5 & 20 & $\begin{array}{l}\text { Backache. } \\
\text { Bilateral third } \\
\text { nerve palsy }\end{array}$ & Numerous & Not done & Not done & $\begin{array}{l}\text { Uncontrolled } \\
\text { leukaemia }\end{array}$ & $\begin{array}{l}\text { Treatment not } \\
\text { given }\end{array}$ & Not given & Not given & $<1$ & $\begin{array}{l}\text { Leukaemic } \\
\text { infiltration of } \\
\text { spinal roots } \\
\text { and dorsal } \\
\text { ganglia. } \\
\text { Perivascular } \\
\text { infiltration of } \\
\text { medulla }\end{array}$ \\
\hline
\end{tabular}

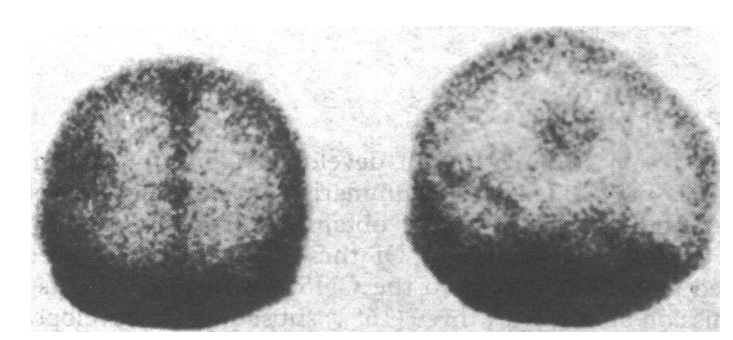

FIG 1-Case 1. ${ }^{99} \mathrm{~m}$ Technetium brain scan at week 99 . Anteroposterior and right lateral views, showing right parietal lesion.

been normal (fig $2 b$ ). The first patient (case 1 ) has remained symptom free and in full remission for nearly three years and has spent only 10 weeks of his total illness in hospital. The second patient (case 2) developed presumed spread to the spinal root about eight months after successful treatment of his intracranial mass. Spinal irradiation has given him symptomatic improvement. This man, despite the complexity of his illness, remained active and continued at his job as a steel erector until he retired three years after the onset of his illness, and he has spent only 12 weeks as an inpatient in hospital.

Necropsy was performed on 27 of the 57 patients who died. The brain and meninges often showed petechial and sometimes gross haemorrhages. Histological examination was not always carried out, however, and although leukaemic infiltration was found only in cases 4 and 5 (table II), the numbers are too small to permit a statement about the incidence of spread to the CNS found post mortem.

\section{Discussion}

The striking feature in three of these five patients with CNS leukaemia was the intracranial masses seen radiologically. This high incidence may represent an atypical distribution in a small series, but a tendency to form local tumours in relation to neural structures, particularly the spinal cord, has been reported in $A M L,{ }^{5}$ and both diffuse brain parenchymal infiltration ${ }^{5} 611$ and discrete intracranial leukaemic nodules have also been recorded.681213 An association of intracranial leukaemic nodules with leucostasis and cerebral haemorrhage in patients

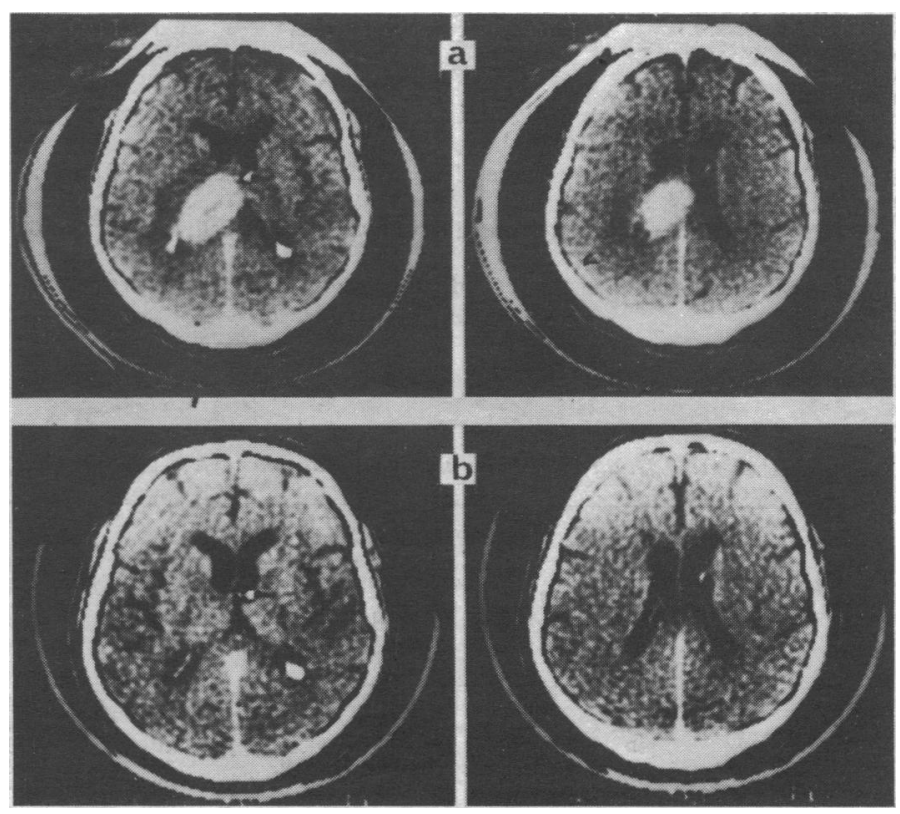

FIG 2-Case 2. CAT scans (contrast enhanced) (a) at week 207, showing large right basal ganglia lesion; $(b)$ at week 214, after cranial irradiation and showing normal scan. The cannula of the Ommaya reservoir may be seen entering the anterior horn of the left lateral ventricle. 

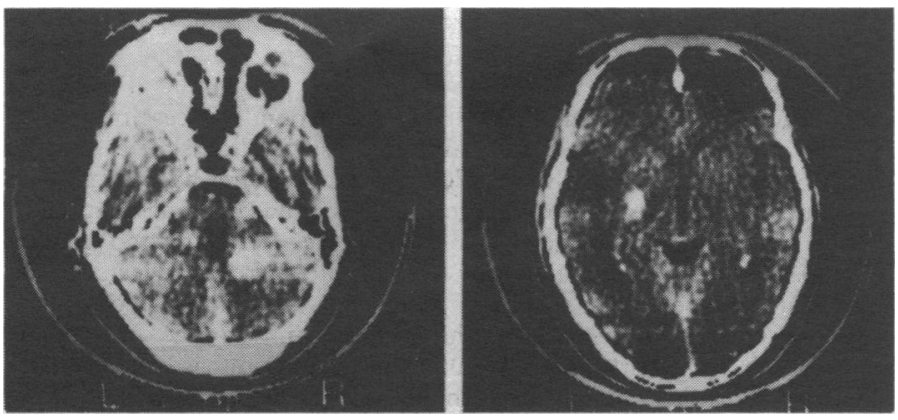

FIG 3-Case 3. CAT brain scan at week 115, showing multiple cerebellar and cerebral lesions (contrast enhanced).

with high preterminal blast-cell counts in the peripheral blood is well recognised ${ }^{14}$ and may have contributed to the appearances in case 3. In none of our cases was there histological proof that the intracranial masses were leukaemic deposits, but in cases 1 and 2 examination of the cerebrospinal fluid (CSF) provided accompanying evidence of CNS infiltration. In all three cases the rapid clinical response to cranial irradiation, and in cases 1 and 2 the return to normal of the radiological appearances, makes any other explanation unlikely. In cases 1,2 , and 3 complaints of minor head, neck, or back pain preceded definitive diagnosis by up to 41 weeks, indicating the importance of increased awareness of the possibility of spread to the CNS. Results in case 2 show that a CAT scan may be useful in defining a solid tumour deposit in patients with localised neurological signs in whom symptoms and signs persist in the absence of CSF pleocytosis. Other workers ${ }^{14}$ have also shown intracerebral leukaemic tumours in acute leukaemia by using CAT scans. In case 3 the finding of multiple intracranial masses together with papilloedema precluded a lumbar puncture, and palliative radiotherapy was given without further investigation.

The reported incidence of clinical CNS disease in AML has varied from $1^{\circ}{ }_{0}$ to $22^{\circ}{ }^{6-815}$ In one necropsy study the incidence of infiltration of the dura was as high as $59 \%$. The incidence of arachnoid infiltration was lower and perivascular infiltration still less common. ${ }^{11}$ The condition was commoner in children than adults and affected male more than female patients. In a more recent study ${ }^{6} 19 \%$ of patients dying of AML had evidence of spread to the CNS, compared with $6.5 \%$ of those who had been diagnosed clinically. In this second study the dura was not always examined, which probably accounts for the wide difference in incidence in these two necropsy series. Again in the second study, as in our own small series, more male patients were affected.

The necropsy studies suggest that clinical diagnosis gives an underestimate, particularly of terminal CNS infiltration. Post- mortem studies have also suggested an association between CNS and other extramedullary infiltration. ${ }^{6}$ Interestingly, three of our patients had monocytic varieties of $A M L$, in which infiltration of skin, gums, or lymph nodes may be particularly prominent, as in cases 4 and 5.

In our series CNS infiltration terminated first remission in only one patient. This has been an uncommon presentation in previous series, ${ }^{7-916}$ and in many patients, as in three of ours, generalised disease has been active at the time of CNS infiltration. Thus when CNS disease occurs in adult AML it is often in the context of generalised disease carrying a poor prognosis, suggesting that haematological relapse may depend more on the failure of current chemotherapy to eliminate systemic disease than on the CNS acting as a "sanctuary site" for leukaemic cells. Our small experience also suggests that CNS infiltration, particularly local leukaemic deposits, may respond dramatically to appropriate radiotherapy or intrathecal cytotoxic drugs, or both, and is compatible with prolonged good quality life provided that it is not associated with uncontrollable generalised leukaemia.

In view of this we think that prophylaxis of the CNS in adult AML should not be given routinely at present. In addition, further improvements in chemotherapy in controlling systemic disease will probably be necessary before trials of CNS prophylaxis may be expected to show any benefit in prolonging leukaemia-free survival.

This work was supported by a grant to STC from the Medical Research Council, London.

We thank Professor D J Weatherall for his helpful advice and Mrs J Packer for typing the manuscript.

\section{References}

1 Pinkel, D, et al, Cancer, 1977, 39, 817.

2 Report to the Medical Research Council by the Leukaemia Committee and Working Party on Leukaemia in Childhood, British Medical fournal, 1973, 2, 381 .

3 Walters, T R, et al, Cancer, 1972, 29, 1057.

${ }^{4} \mathrm{Kay}, \mathrm{H}$ E, Archives of Disease in Childhood, 1976, 51, 73.

${ }^{5}$ Dawson, D M, Rosenthal, D S, and Moloney, W C, Annals of Internal Medicine, 1973, 79, 541

6 Wolk, R W, et al, Cancer, 1974, 33, 863.

'Renoux, M, et al, Nouvelle Revue Française d'Hématologie, 1977, 18, 23.

${ }^{8}$ Ruggero, D, et al, Haematologica, 1977, 62, 312.

9 Armitage, J O, and Burns, C P, Cancer, 1978, 41, 697

${ }^{10}$ Medical Research Council, British fournal of Cancer, 1978, 31, 1.

${ }^{11}$ Moore, E W, et al, Archives of Internal Medicine, 1960, 105, 451.

12 Demary, M J, et al, Surgical Neurology, 1976, 6, 353.

13 Gastaut, J-A, Gastaut, J-L, and Carcassonne, Y, Cancer, 1978, 41, 487

${ }^{14}$ Freirich, E J, et al, Cancer, 1960, 13, 146.

15 Ansari, B M, Thompson, E N, and Whittaker, J A, British fournal of Haematology, 1975, 31, 269.

${ }^{16}$ Clarkson, B D, et al, Cancer, 1975, 36, 775.

(Accepted 15 November 1978)
ONE HUNDRED YEARS AGO A very striking example of the interesting and relatively rare phenomenon of phosphorescent meat is recorded by Dr Nuesch in the Mittheilungen der Naturf. Gesellschaft in Bern, 1878. Hearing one evening a cry of alarm issuing from the pantry, he hastened thither, and saw, to his astonishment, that about a dozen of pork-chops, which were lying in a dish, were illuminating the whole place with a greenish light, which was so strong that the features of the persons who stood by could be clearly distinguished, and also the minutes and seconds on the face of a watch. On being examined under the microscope, the surface of the chops was found to be covered with a number of minute bacteria, of various forms and sizes, which were phosphorescent; some of them remained motionless, while others moved about in various directions. The meat was not bad, nor had it any peculiar smell. The butcher, having been questioned on the subject, said that for several weeks all the meat, even the beef, which he kept in his shop, which was very clean, had been phosphorescent. The author went to the place and convinced himself that one-half of the slaughtered oxen, cows, and pigs were most brilliantly phosphorescent, especially on the line between the fat meat and the lean. The brilliant mass spread more and more over the pieces of meat, and could be removed with a knife to other portions of the bodies; if the latter were fresh, the phosphorescent mass quickly increased. Potatoes or boiled white of egg did not emit much light; blood, whether fresh or old, did not phosphoresce. As soon as putrification set in, the brilliancy entirely disappeared; and the same thing happened when sulphurous, carbolic, or salicylic acid, or alcohol, was added to the preparation. In the butcher's shop, the phenomenon lasted from Easter to Whitsuntide, as long as the mean temperature did not rise beyond $50 \mathrm{deg}$. Fahr. Its disappearance may have been owing either to the rise in the temperature, or to the vapours of the carbolic acid and other disinfectants which were used. The same phenomenon has been met with occasionally before: in 1592, at Padua, where it was described by Fabricius ab Aquapendente; once in Austria; and a third time, in 1868, in Bern, and in Heidelberg in the dissecting-room of the University. (British Medical fournal, 1879.) 